\title{
AIR POLLUTION STUDY IN MACEDONIA USING A MOSS BIOMONITORING TECHNIQUE, ICP-AES AND AAS
}

\section{Lambe Barandovski ${ }^{1}$, Trajče Stafilov²*, Robert Šajn ${ }^{3}$, Marina V. Frontasyeva ${ }^{4}$, Katerina Bačeva ${ }^{2}$}

\author{
${ }^{1}$ Institute of Physics, Faculty of Natural Sciences and Mathematics, \\ Ss. Cyril and Methodius University, POB 162, 1000 Skopje, Republic of Macedonia \\ ${ }^{2}$ Institute of Chemistry, Faculty of Natural Sciences and Mathematics, \\ Ss. Cyril and Methodius University, POB 162, 1000 Skopje, \\ Republic of Macedonia \\ ${ }^{3}$ Geological Survey of Slovenia, Dimičeva ul. 14, 1000 Ljubljana, Slovenia \\ ${ }^{4}$ Frank Laboratory of Neutron Physics, Joint Institute for Nuclear Research, \\ 141980 Dubna, Moscow Region, Russia \\ trajcest@pmf.ukim.mk
}

\begin{abstract}
In the framework of the International Cooperative Programme on Effects of Air Pollution on Natural Vegetation and Crops under the auspices of the United Nations Economic Commission for Europe (UNECE-ICP Vegetation) Convention on Long-Range Transboundary Air Pollution (LRTAP), in 2002 and 2005, a moss biomonitoring technique was applied to air pollution studies in the Republic of Macedonia. The third moss survey took place in August and September 2010 when 72 samples of the terrestrial mosses Homalothecium lutescens and Hypnum cupressiforme were collected over the territory of the Republic of Macedonia, using the same sampling network grid as for the previous surveys. Using inductively coupled plasma-atomic emission spectrometry (ICP-AES) and atomic absorption spectrometry (AAS), a total of 19 elements (Al, B, Ba, Ca, Cd, Cr, Cu, Fe, Hg, K, Li, Mg, Mn, Ni, P, Pb, Sr, V and Zn) were determined. To reveal hidden multivariate data structures and to identify and characterize different pollution sources Principal Component Analysis was used. Distributional maps were prepared to point out the regions most affected by pollution and related to known sources of contamination. As in the previous surveys, the regions near the towns of Skopje, Veles, Tetovo, Radoviš and Kavadarci were found to be most affected by pollution, even though the median elemental content in the mosses in 2010 for $\mathrm{Cd}, \mathrm{Cr}, \mathrm{Cu}, \mathrm{Ni}, \mathrm{Pb}$ and $\mathrm{Zn}$ was slightly lower than in the previous surveys. For the first time, $\mathrm{P}$ content in the moss samples was analyzed, and a higher content of this element as well as $\mathrm{K}$ in the mosses was observed in the agricultural regions of the country.
\end{abstract}

Keywords: Moss; biomonitoring; air pollution; heavy metals; Macedonia

\section{ПРОУЧУВАЊЕ НА ЗАГАДУВАњЕТО НА ВОЗДУХОТ ВО МАКЕДОНИЈА СО ПРИМЕНА НА БИОМОНИТОРИНГ НА МОВ, ICР-АЕS И ААS}

Во рамките на меѓународната програма за изучување на ефектите од загадувањето на воздухот врз природната вегетација и житните култури, под покровителството на Економската комисија за Европа на Обединетите Нации (UNECE-ICP Vegetation) и Конвенцијата за следење на 


\begin{abstract}
прекуграничното загадување (LRTAP), во 2002 и 2005 година беше извршен биомониторинг на мов заради проучување на загадувањето на воздухот во Република Македонија. Третото по ред собирање на примероците беше направено во август и септември 2010 година кога од целата територија на Република Македонија беа собрани 72 примерока од терестријалните видови мов Homalothecium lutescens и Hypnum cupressiforme, користејќи идентична мрежа за собирање на примероците како и во претходните испитувања. Со примена на атомската емисиона спектрометрија со индуктивно спрегната плазма (ICP-AES) и атомската апсорпциона спектрометрија (AAS) е определена содржината на 19 елементи (Al, B, Ba, Ca, Cd, Cr, Cu, Fe, Hg, K, Li, Mg, Mn, Ni, P, Pb, Sr, V и Zn). За да се откријат скриените мултиваријантни структури на податоците, како и да се одредат различните извори на загадувањето, беше применет методот на главни компоненти. Со цел да се одредат местата со најголемо загадување и тие да се поврзат со познатите извори на загадувањето, беа изработени карти на кои е прикажана дистрибуцијата на одделните елементи. Како и во претходните истражувања, најголемо загадување на воздухот е во регионите во близина на Скопје, Велес, Тетово, Радовиш и Кавадарци, иако медијаните на $\mathrm{Cd}, \mathrm{Cr}, \mathrm{Cu}, \mathrm{Ni}, \mathrm{Pb}$ и $\mathrm{Zn}$ во примероците од мов анализирани во 2010 година се помали од оние добиени во претходните истражувања. За првпат во примероците од мов е извршено определување на содржината на Р и највисоки вредности на овој елемент и на К се забележани во примероците собрани од земјоделските региони.
\end{abstract}

Клучни зборови: мов; биомониторинг; загадување на воздух; тешки метали; Македонија

\section{INTRODUCTION}

Biomonitoring in the most general sense can be defined as the use of organisms (biomaterials) to obtain quantitative information and some characteristics of the biosphere. Bioindicator or biomonitor are terms used to refer to an organism (or a part of the organism), that reacts on the occurrence of pollutants on the basis of specific symptoms, reactions, morphological changes or concentrations. Usually, organisms can be classified according to the way in which the reaction is manifested: reaction indicators, which have a sensitive reaction to air pollutants and which are used especially in studying the effects of pollutants on their physiological and ecological functioning, and accumulation indicators that readily accumulate a range of pollutants and therefore are used especially when monitoring the amount of pollutants and their distribution [1]. A general advantage of the biomonitoring approach is related primarily to the permanent and common occurrence of the organism in the field even in remote areas, the ease of sampling and the absence of any expensive technical equipment, if proper selection of an organism has been made. Due to their common occurrence, lichens and mosses are two biological species that are most commonly used as biomonitors [2].
Terrestrial mosses as biomonitors of atmospheric deposition of trace elements were introduced in Scandinavian countries $[2,3]$ and shortly after that, usage of the mosses to assess the atmospheric deposition of metals was widely accepted in Europe [1, 4, 5], North America, and some of the countries in Latin America and Asia [6-10]. Although the passive biomonitoring technique is commonly used, there is a growing interest in using the active technique, particularly in heavily polluted areas and urban areas where mosses are not often found in sufficient quantities or are absent [1013]. Carpet-forming moss species have many advantages as biomonitors compared to higher plants and lichens [14-17].

Pleurozium schreberi (Brid.) Mitt. and Hylocomium splendens (Hedw.) Schimp. are the moss species that are most commonly used for biomonitoring of atmospheric deposition of trace elements and were suggested by the guidelines of the International Cooperative Programme on Effects of Air Pollution on Natural Vegetation and Crops (ICP Vegetation) monitoring manual for the 2005/2006 survey, as well as the procedure used in the previous European moss surveys [4, 18]. However, in areas where these two species cannot be found, alternative moss species are used like Hypnum cuppressiforme (Hedw.), Homalothecium lute- 
scens (Hedw.) Robins., Hylocomium splendens (Hedw.) Schimp. BS\&G., Sphagnum girgensohnii Russow, Brachythecium salebrosum (Web. \& Mohr) BS\&G., Scleropodium purum (Hedw.) Limpr., etc. [12-14, 18, 19].

The Republic of Macedonia was involved in the UNECE ICP Vegetation - Heavy Metals in European Mosses, for the first time in 2002 (survey 2000/2001) and again in 2005 when atmospheric deposition of trace elements was studied over the entire territory of the country using samples of terrestrial mosses Hypnum cupressiforme and Homalothecium lutescens [20-22] (given as Camptothecium lutescens in previously published papers [20, 21]). Analysing the results from the first survey, the most important emission sources were determined (mines and drainage systems and smelters near the towns of Veles, Tetovo, Kavadarci and Radoviš), and some uranium deposition patterns were described by the activity of power plants using lignite coal as fuel. A comparison of the results was made with results obtained from similar studies performed in neighboring countries [23-27], as well as a comparison with more pristine territories in other parts of Europe $[5,28-30]$. The results from the second survey showed increasing trends of elemental content in mosses that are connected with anthropogenic sources, such as $\mathrm{Cd}, \mathrm{Co}, \mathrm{Pb}, \mathrm{Hg}$ and $\mathrm{Ni}$ in 2005 compared with the previous survey, but also a decreasing trend in the content of some elements in mosses such as $\mathrm{As}, \mathrm{Cr}, \mathrm{Cu}, \mathrm{Sb}$ and Se.

The aim of this paper was (1) to present the results obtained from the 2010 deposition survey in the Republic of Macedonia based on terrestrial moss analysis, using atomic absorption spectrometry (AAS) and inductively coupled plasma-atomic emission spectrometry (ICP-AES) as analytical techniques, (2) to report on temporal trends in the heavy metal content in mosses in the Republic of Macedonia between 2002 and 2010, and (3) to classify data and to identify possible sources of the elements and their deposition patterns.

\section{EXPERIMENTAL}

\subsection{Study area}

The Republic of Macedonia is a landlocked country situated in the central part of the Balkan Peninsula and it has a total area of $25,713 \mathrm{~km}^{2}$. The total population of the country is two million and around $60 \%$ of the population lives in urban areas [31].

The climate is unique, and it is transitional from Mediterranean to the south of the state to continental in the north. Annual precipitation varies from $1400 \mathrm{~mm}$ in the western mountainous area to $500 \mathrm{~mm}$ in the eastern parts of the country. The wind direction in different parts of Macedonia depends on the orographic conditions. The main industrial capacities in the country are located in Skopje (steel and ferroalloy production and steel processing), Veles (lead, zinc and cadmium smelter and refinery), Radoviš (copper mine and flotation), Kavadarci (ferro-nickel smelter), Tetovo (previously active ferro-chromium smelter and at present ferro-silicon smelter) and Kičevo and Bitola (thermoelectric power plants using lignite as fuel). There are three mines with flotation plants for lead and zinc and one for copper in the eastern part of the Republic of Macedonia. All these industrial activities affect environmental pollution in the mentioned areas with different heavy metals [21, 32-37].

The Macedonian basement consists of four major tectonic units: the Serbo-Macedonian massif (SMM), the Vardar zone (VZ), the Pelagonian massif (PM) and the West-Macedonian zone (WMZ) $[38,39]$. A detailed description of the study area and a lithological map of the Republic of Macedonia are given elsewhere [22].

\subsection{Moss species and sampling}

Moss sampling was performed according to the guidelines of the UNECE-ICP Vegetation monitoring manual for air pollution monitoring of the atmospheric deposition of heavy 
metal deposition using bryophytes, as well as the procedure used in the previous European moss surveys [40]. At 72 locations over the entire territory of the Republic of Macedonia during August and September 2010, samples from the species Homalothecium lutescens (Hedw.) Robins. and Hypnum cupressiforme (Hedw.) were collected. To aid the analysis of temporal trends in the concentration of heavy metals in mosses, samples were collected from the same sites as in the previous surveys. Both moss species were present at some sampling sites, but no single species was present at all sampling sites due to the large number of types of soil as well as the different climatic conditions over the country. Interspecies comparison performed for the sampling sites where both moss species were present showed an equal content of ele- ments within the error estimates. The distribution of the sampling sites is shown in Figure 1.

Samples were collected at least $300 \mathrm{~m}$ from main roads and populated areas and at least $100 \mathrm{~m}$ from local roads, and $200 \mathrm{~m}$ from villages or single houses. As much as possible, the samples were taken from small forest clearings to reduce the through-fall effects. Sampling below a forest canopy of shrubs and large-leafed herbs was avoided. Five to ten sub-samples were collected within an area of $50 \mathrm{~m} \times 50 \mathrm{~m}$ and combined in one sample in order to make the moss samples representative for the site. To prevent any contamination, sampling and sample handling was performed using disposable polyethylene gloves for each sample.

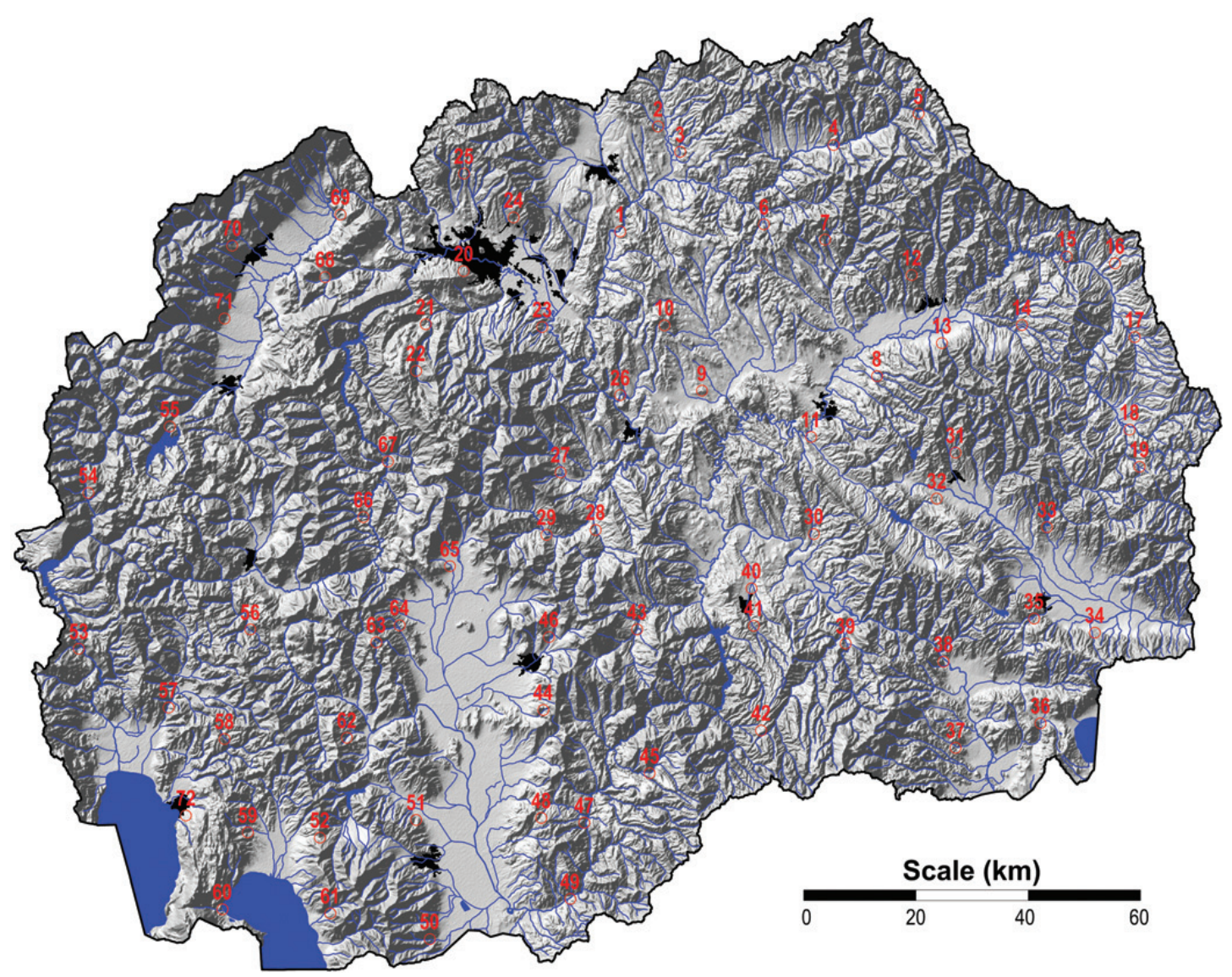

Fig. 1. Sampling network points in the Republic of Macedonia 
All the collected samples, after they were cleaned of extraneous material (litter and dead leaves), were stored in paper bags, carefully closed to prevent contamination during transportation and transferred to the analytical laboratory. For each sampling site, longitude, latitude and altitude were noted using GPS (Greenwich co-ordinates, $360^{\circ}$ system) as well as details about the sampling site: date and time of sampling, weather conditions, nearby vegetation topography and land use.

\subsection{Sample preparation and digestion}

In the laboratory, the samples were cleaned but not subjected to any further washing and dried to a constant weight for 48 hours at room temperature. Green and green-brown parts of the moss that correspond to three years of moss growth were sorted and prepared for analysis.

For digestion, moss samples $(0.5000 \mathrm{~g})$ were placed in Teflon digestion vessels, and 7 $\mathrm{ml}$ of trace pure $\mathrm{HNO}_{3}$ (Merck, Germany) and 2 $\mathrm{ml} \mathrm{H}_{2} \mathrm{O}_{2}$ p.a. (Alkaloid, Macedonia) were added, and the vessels were capped closed, tightened and placed in the rotor of a Mars microwave digestion apparatus (CEM, USA). Plant samples were digested at $180{ }^{\circ} \mathrm{C}$. After cooling, the digested samples were quantitatively transferred into $25 \mathrm{ml}$ calibrated flasks.

\subsection{Reagents and standards}

Stock solutions (11355-ICP Multi Element Standard IV, Merck) of 23 elements with a concentration of $1000 \mathrm{mg} \mathrm{l}^{-1}$ served for further dilutions. All chemical reagents used were of analytical grade: HF, p.a. (Fluka, Germany); perchloric acid, p.a. (Alkaloid, Macedonia); $\mathrm{HCl}$, p.a. (MERCK, Germany); $\mathrm{H}_{2} \mathrm{O}_{2}, p . a$. (MERCK, Germany), and $\mathrm{HNO}_{3}$, p.a. (MER$\mathrm{CK}$, Germany). All vessels used were precleaned by leaching for $24 \mathrm{~h}$ each in proportions of 1 part $\mathrm{HNO}_{3}$ and 3 parts $\mathrm{HCl}$, followed by rinsing with double distilled water.

\subsection{Instrumentation}

The analyses were performed at the Institute of Chemistry, Faculty of Natural Sciences and Mathematics in Skopje. All analyzed elements (Al, B, Ba, Ca, Cd, Co, Cr, $\mathrm{Cu}, \mathrm{Fe}, \mathrm{K}, \mathrm{Li}, \mathrm{Mg}, \mathrm{Mn}, \mathrm{Ni}, \mathrm{P}, \mathrm{Pb}, \mathrm{Sr}, \mathrm{V}$ and $\mathrm{Zn}$ ) were determined by the application of ICPAES (Varian, 715-ES) applying an ultrasonic nebulizer CETAC (ICP/U-5000AT ${ }^{+}$) for better sensitivity, electrothermal AAS, ETAAS (Varian SpectrAA 640Z) for the analysis of $\mathrm{Cd}$ and $\mathrm{Pb}$, and $\mathrm{CV}$-AAS for $\mathrm{Hg}$. The optimal instrumental parameters for these techniques are given in our previously published paper [41].

\subsection{Quality control}

Quality control was ensured using standard moss reference materials M2 and M3, which were prepared for the European Moss Survey [42]. There was good agreement between the measured concentrations and the recommended values. The method of standard addition was also applied and quantitative recoveries were achieved for most of the elements.

\subsection{Data processing and statistical analysis}

Data processing was performed using the statistical software Stat Soft (Version 9) after all field observations, analytical data and measurements were entered into a data matrix. Parametric and non-parametric statistical methods were used, and normality tests of data distributions were performed [43, 44]. For the set of the samples, the arithmetical mean, geometrical mean, median, minimum, maximum, $10^{\text {th }}$ percentile, $90^{\text {th }}$ percentile, arithmetic standard deviation, geometric standard deviation, coefficient of variance, skewness and kurtosis were calculated, for the content of all 19 elements.

On the basis of normality tests and visual inspection of individual histograms of the dis- 
tribution of the content of 18 analyzed elements in the samples ( $\mathrm{Al}, \mathrm{B}, \mathrm{Ba}, \mathrm{Ca}, \mathrm{Cd}, \mathrm{Cr}, \mathrm{Cu}, \mathrm{Fe}$, $\mathrm{Hg}, \mathrm{K}, \mathrm{Li}, \mathrm{Mg}, \mathrm{Mn}, \mathrm{Ni}, \mathrm{P}, \mathrm{Pb}, \mathrm{Sr}, \mathrm{V}$ and $\mathrm{Zn}$ ), logarithms of content values were considered as normally distributed for all the elements except for $\mathrm{Ca}, \mathrm{K}$ and $\mathrm{P}$, where normality was assumed for the natural values. The degree of association of chemical elements was assessed using the linear coefficient of correlation. $\mathrm{Ab}$ solute values $r>0.50$ indicated a good relation between the variables [45].

To explain the variation and to reveal associations between chemical elements, all moss samples were examined by multivariate analysis. Multivariate cluster and R-mode factor analyses were used [46-48] The multivariate statistical cluster and factor analyses were performed on 15 selected chemical elements (Al, $\mathrm{Ba}, \mathrm{Cd}, \mathrm{Cr}, \mathrm{Cu}, \mathrm{Fe}, \mathrm{K}, \mathrm{Mg}, \mathrm{Mn}, \mathrm{Ni}, \mathrm{P}, \mathrm{Pb}, \mathrm{Sr}, \mathrm{V}$ and $\mathrm{Zn}$ ). Other elements were eliminated from further analysis to satisfy the criteria of dimension variables based on the number of observations and because of their tendency to form their own clusters, not showing a reasonable connection with other chemical elements. Factor analysis (FA) was performed on variables standardized to zero mean and unit standard deviation. For orthogonal rotation, the varimax method was used. With FA, the characteristics of the 15 individual elements were reduced to four synthetic variables, i.e. factors (F1 to F4), which accounted for $78.6 \%$ of the total variability of the treated elements.

Universal kriging with the linear variogram interpolation method was applied for the construction of maps showing the spatial distribution of factor scores, as well as maps displaying the distribution of heavy metals in moss samples [46, 49]. The basic grid cell size for interpolation was $1 \times 1 \mathrm{~km}$. For class limits, the percentile values of distribution of interpolated values were chosen with following percentile values: $0-10,10-25,25-40,40-60$, 60-75, 75-90 and 90-100.

\section{RESULTS AND DISCUSSION}

The descriptive statistics of the 19 analyzed elements in all collected moss samples $(n=72)$ is shown in Table 1. All values in Table 1 are given in $\mathrm{mg} \mathrm{kg}^{-1}$, dry weight. In Table 2 , the median values and minimum-maximum ranges for the contents of all elements are compared with the data obtained in the 2005 and 2002 moss surveys in the Republic of Macedonia (number of sampling sites $n=73$ in 2002 and $n=72$ in 2005) [21, 22], the data obtained from the European Moss Survey program in $2005 / 2006(n=6049)$ [29], as well as the data from 2010 moss survey in Norway $(n=464)$ [50].

As it can be seen from the results presented in Table 2 and the reported results for other European countries, for median values and minimum-maximum ranges, most of the European countries reported lower median data for $\mathrm{As}, \mathrm{Cd}, \mathrm{Cr}, \mathrm{Cu}, \mathrm{Fe}, \mathrm{Hg}, \mathrm{Ni}, \mathrm{Pb}, \mathrm{V}$ and $\mathrm{Zn}$ in the mosses analyzed in 2005 than those analyzed in 2002 [30]. The situation in the Republic of Macedonia concerning the content of $\mathrm{Cd}$, $\mathrm{Ni}, \mathrm{Pb}$ was the opposite. The higher content of $\mathrm{Cd}$ and $\mathrm{Pb}$ in the mosses was explained by pollution from the lead-zinc smelter in Veles which operated until 2003, as well as the pollution that comes from the open slag waste dump of this smelter in the vicinity of Veles and the usage of leaded gasoline in the country in that period. The most evident difference was for the Ni content, which was 2.5-fold higher than its content in moss samples from the 2002 survey, which was explained by the increase in production capacity of the ferro-nickel smelter near Kavadarci beginning in 2004. The median content of $\mathrm{As}, \mathrm{Cu}, \mathrm{Fe}, \mathrm{Hg}, \mathrm{V}$ and $\mathrm{Zn}$ in the mosses in Macedonia were not significantly changed in the two surveys, although slightly lower median values were observed in 2005 compared to 2002 for $\mathrm{As}, \mathrm{Cu}, \mathrm{Fe}, \mathrm{V}$ and $\mathrm{Zn}$. The comparison of the median values for $\mathrm{Cr}$, from the two previous surveys in Macedonia, showed a decrease in the content in the mosses. A comparison of the results from the surveys in 
Table 1

Descriptive statistics of measurements for moss samples (in $\mathrm{mg} \mathrm{kg}^{-1}$ )

\begin{tabular}{lcccccccccccccc}
\hline \hline & $n$ & $\mathrm{Dis}$ & $X_{a}$ & $X_{g}$ & $M d$ & $P_{10}$ & $P_{90}$ & $\min$ & $\max$ & $s_{a}$ & $s_{g}$ & $\mathrm{CV}$ & $\mathrm{A}$ & $\mathrm{E}$ \\
\hline $\mathrm{Al}$ & 72 & $\log$ & 2200 & 1900 & 1900 & 1100 & 3400 & 540 & 8700 & 1400 & 160 & 64 & 0.43 & 0.48 \\
$\mathrm{~B}$ & 72 & $\log$ & 7.9 & 3.2 & 6.6 & 0.20 & 14 & 0.010 & 94 & 12 & 1.4 & 150 & -1.33 & 1.85 \\
$\mathrm{Ba}$ & 72 & $\log$ & 41 & 33 & 34 & 13 & 76 & 7.1 & 240 & 32 & 3.7 & 78 & -0.03 & 0.34 \\
$\mathrm{Ca}$ & 72 & $\mathrm{~N}$ & 7300 & 7100 & 7100 & 5500 & 9800 & 2900 & 12000 & 1700 & 210 & 24 & 0.26 & -0.08 \\
$\mathrm{Cd} *$ & 72 & $\log$ & 0.29 & 0.23 & 0.22 & 0.088 & 0.44 & 0.068 & 2.2 & 0.29 & 0.034 & 100 & 0.59 & 1.28 \\
$\mathrm{Cr}$ & 72 & $\log$ & 4.7 & 3.8 & 3.5 & 2.2 & 7.5 & 1.0 & 40 & 5.0 & 0.59 & 107 & 1.41 & 3.99 \\
$\mathrm{Cu}$ & 72 & $\log$ & 4.0 & 3.8 & 3.5 & 2.6 & 6.2 & 2.0 & 11 & 1.6 & 0.19 & 40 & 0.71 & 0.64 \\
$\mathrm{Fe}$ & 72 & $\log$ & 1700 & 1500 & 1500 & 800 & 2900 & 510 & 6300 & 1100 & 130 & 61 & 0.39 & 0.06 \\
$\mathrm{Hg}$ & 72 & $\log$ & 0.11 & 0.09 & 0.09 & 0.05 & 0.16 & 0.01 & 0.59 & 0.09 & 0.01 & 0.01 & 3.57 & 14.2 \\
$\mathrm{~K}$ & 72 & $\mathrm{~N}$ & 4800 & 4700 & 4600 & 3800 & 6100 & 2100 & 7600 & 960 & 110 & 20 & 0.47 & 0.98 \\
$\mathrm{Li}$ & 72 & $\log$ & 1.2 & 1.0 & 1.0 & 0.52 & 2.0 & 0.29 & 5.1 & 0.75 & 0.088 & 63 & 0.29 & 0.68 \\
$\mathrm{Mg}$ & 72 & $\log$ & 2000 & 1900 & 1900 & 1500 & 2800 & 610 & 4900 & 630 & 74 & 31 & -0.30 & 3.42 \\
$\mathrm{Mn}$ & 72 & $\log$ & 150 & 130 & 130 & 56 & 300 & 30 & 440 & 96 & 11 & 63 & -0.15 & -0.77 \\
$\mathrm{Ni}$ & 72 & $\log$ & 6.4 & 4.1 & 3.5 & 2.5 & 11 & 1.3 & 52 & 9.8 & 1.2 & 152 & 1.40 & 2.76 \\
$\mathrm{P}$ & 72 & $\mathrm{~N}$ & 1100 & 1100 & 1100 & 800 & 1600 & 420 & 2000 & 310 & 37 & 27 & 0.38 & 0.35 \\
$\mathrm{~Pb} *$ & 72 & $\log$ & 5.4 & 4.7 & 4.6 & 2.4 & 8.4 & 1.9 & 22 & 3.3 & 0.39 & 62 & 0.43 & 0.25 \\
$\mathrm{Sr}$ & 72 & $\log$ & 28 & 24 & 24 & 11 & 49 & 5.6 & 100 & 16 & 1.9 & 59 & -0.15 & 0.13 \\
$\mathrm{~V}$ & 72 & $\log$ & 3.9 & 3.3 & 3.5 & 1.5 & 6.2 & 1.0 & 17 & 2.7 & 0.32 & 69 & 0.22 & 0.47 \\
$\mathrm{Zn}$ & 72 & $\log$ & 30 & 20 & 20 & 8.0 & 49 & 1.0 & 360 & 45 & 5.3 & 151 & -0.23 & 2.86 \\
\hline \hline
\end{tabular}

* - determined by AAS; $n$ - number of samples; Dis - distribution (log - lognormal, N - normal); $X_{a}$ - arithmetical mean; $X_{g}$ - geometrical mean; $M d$ - median; $P_{10}-10$ percentile; $P_{90}-90$ percentile; min - minimum; max - maximum; $s_{a}-$ standard deviation; $s_{g}-$ geometric standard deviation; $C V$ - coefficient of variance; A - skewness; E- kurtosis.

2002 and 2005 with the median values reported for Europe showed that the median values for the Republic of Macedonia were higher for all elements.

The comparison made for the median values calculated for the results obtained from the moss samples in Macedonia in 2010 with the median values for Europe calculated on the basis of the content of the elements in 6049 moss samples collected in 34 European countries shows that Macedonia had higher median values for $\mathrm{Cd}$ (1.5), $\mathrm{Cr}$ (2.9), $\mathrm{Fe}$ (2.8), $\mathrm{Ni}$ (2.6), $\mathrm{Pb}$ (4.3), $\mathrm{V}(2.3)$ and $\mathrm{Zn}(1.1)$ and only lower median value for $\mathrm{Cu}(0.9)$. The number in the brackets represents the ratio between the median values for Macedonia and the median values for 34 European countries.

Analysing the trend of the median values calculated for the three moss surveys in
Macedonia, it can be seen that in the last survey, lower median values were observed for all elements that were analyzed for the moss survey in 2010. The analysis with AAS as well as ICPAES (for the 2010 survey) was based on nitric acid digestion, using non-destructive NAA determination (for 2002 and 2005 surveys), the entire amount of the elements in question was analyzed. The lower median values for $\mathrm{Al}, \mathrm{Ba}$, $\mathrm{Ca}, \mathrm{Cr}, \mathrm{Cu}, \mathrm{Fe}, \mathrm{K}, \mathrm{Mg}, \mathrm{Mn}, \mathrm{Na}, \mathrm{Ni}, \mathrm{Sr}, \mathrm{V}$ and $\mathrm{Zn}$ can be explained by the difference in the analytical techniques and potentially leaving out a fraction of the elements due to their refractory minerals [51].

In the 2002 and 2005 surveys, $\mathrm{Cd}, \mathrm{Cu}$ and $\mathrm{Pb}$ were analyzed by AAS and all other elements were analyzed by NAA. In 2010, $\mathrm{Pb}$ was also analyzed by $\mathrm{AAS}$, but $\mathrm{Cd}$ and $\mathrm{Cu}$ were analyzed by ICP-AES (Table 2). Both 


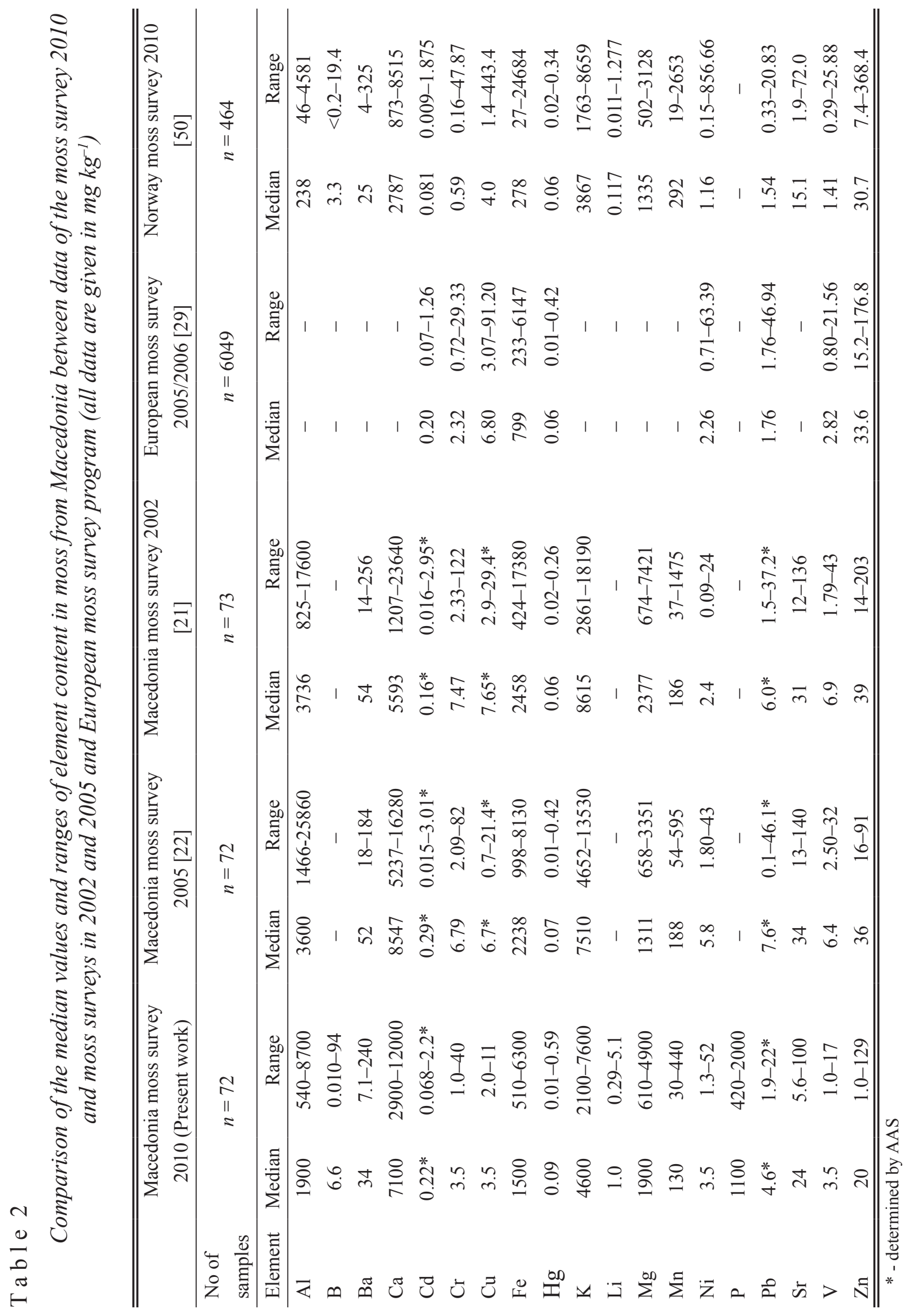


techniques are based on nitric acid digestion and the comparison of the median values shows that the content of $\mathrm{Cd}, \mathrm{Cu}$ and $\mathrm{Pb}$ in mosses in 2010 was lower than the content of the elements in the mosses in the two previous surveys. This result can be explained by the closing of the lead-zinc smelter in the town of Veles in May 2004 and a significant reduction in the use of leaded gasoline in the past few years.

In comparison with the only published results from the moss survey in 2010, the results from Norway, which is usually considered one of the most pristine areas in Europe, Macedonia had a higher median value for the element content in mosses for all elements except for $\mathrm{Mn}$ and $\mathrm{Zn}$. A comparison of the maximum values obtained for the two surveys shows that maximum values were higher in Macedonia for $\mathrm{Al}, \mathrm{B}, \mathrm{Ba}, \mathrm{Ca}, \mathrm{Cd}, \mathrm{Li}, \mathrm{Mg}, \mathrm{Na}, \mathrm{Ni}, \mathrm{Pb}$ and Sr. The opposite situation was observed for the maximum values of $\mathrm{Cr}, \mathrm{Cu}, \mathrm{Fe}, \mathrm{K}, \mathrm{Mn} \mathrm{V}$, and $\mathrm{Zn}$. The much higher median content of crustal elements such as $\mathrm{Al}, \mathrm{Ba}, \mathrm{Ca}, \mathrm{Fe}, \mathrm{Li}$ can be explained by the drier climate in Macedonia than Norway and the high influence of the content of these elements in mosses due to wind erosion, especially in the dry periods of the year. The lower median value for $\mathrm{Mn}$ can be explained by the lower density of higher plants in Macedonia than in Norway, since it is believed that there is an influence of uptake and secretion by higher plants on the content of $\mathrm{Mn}$ in mosses. Some conclusions can also be extracted from the observation of the maximum values for this element. The higher maximum values in Norway for some elements but lower median values than the median values for Macedonia can be explained by the small influence of local industries in Mo, Rana and Odda (Norway) to air pollution in the entire country.

\subsection{Associations between chemical elements}

The matrix of rotated factor loadings is given in Table $3.78 .6 \%$ of the variability of the treated elements was explained by four identified factors. These factors were identified by a visual inspection of similarities in the spatial distribution of element patterns, the correlation coefficients, a comparison of basic statistical parameters and the results of multivariate analyses.

$\mathrm{T}$ a b 1 e 3

Matrix of rotated factor loadings

$(n=72,15$ selected elements, $F>0.55)$

\begin{tabular}{lccccc}
\hline \hline Element & $\mathrm{F} 1$ & $\mathrm{~F} 2$ & $\mathrm{~F} 3$ & $\mathrm{~F} 4$ & $\begin{array}{c}\text { Com } \\
\text { (\%) }\end{array}$ \\
\hline $\mathrm{Al}$ & $\mathbf{0 . 8 6}$ & 0.21 & 0.36 & -0.01 & 91.0 \\
$\mathrm{~V}$ & $\mathbf{0 . 8 3}$ & 0.24 & 0.33 & -0.11 & 87.4 \\
$\mathrm{Fe}$ & $\mathbf{0 . 8 1}$ & 0.24 & 0.46 & -0.09 & 93.3 \\
$\mathrm{Ba}$ & $\mathbf{0 . 7 7}$ & 0.04 & -0.09 & 0.29 & 68.1 \\
$\mathrm{Li}$ & $\mathbf{0 . 7 6}$ & 0.20 & 0.47 & 0.02 & 83.4 \\
$\mathrm{Sr}$ & $\mathbf{0 . 7 5}$ & 0.09 & 0.05 & 0.21 & 61.9 \\
$\mathrm{Cu}$ & 0.39 & $\mathbf{0 . 5 6}$ & 0.30 & 0.20 & 60.5 \\
$\mathrm{Zn}$ & 0.17 & $\mathbf{0 . 8 8}$ & 0.12 & 0.08 & 82.8 \\
$\mathrm{~Pb}$ & 0.15 & $\mathbf{0 . 7 7}$ & 0.16 & -0.36 & 76.8 \\
$\mathrm{Cd}$ & 0.06 & $\mathbf{0 . 8 8}$ & 0.02 & 0.14 & 80.6 \\
$\mathrm{Mg}$ & 0.51 & -0.03 & $\mathbf{0 . 5 7}$ & 0.22 & 63.8 \\
$\mathrm{Cr}$ & 0.36 & 0.19 & $\mathbf{0 . 8 6}$ & -0.09 & 91.3 \\
$\mathrm{Ni}$ & 0.11 & 0.17 & $\mathbf{0 . 8 7}$ & -0.15 & 82.6 \\
$\mathrm{P}$ & 0.20 & 0.04 & -0.18 & $\mathbf{0 . 8 2}$ & 74.4 \\
$\mathrm{~K}$ & 0.04 & 0.04 & 0.06 & $\mathbf{0 . 8 9}$ & 80.8 \\
\hline $\mathrm{Var}(\%)$ & 29.7 & 18.3 & 17.9 & 12.7 & 78.6 \\
\hline \hline
\end{tabular}

F1, F2, F3 and F4 - Factor loading; Var - Variance (\%); Com - Communality $(\%)$

Factor 1 (Al, V, Fe, Ba, Li, Sr) is the strongest factor, representing nearly $30 \%$ of the total variability. This group represents chemical elements that are probably naturally distributed. The content of these elements in mosses is significantly influenced by mineral particles released into the atmosphere by wind erosion of local sources or particles attached to the moss in the periods when the soil surface is covered by water. The distribution of these elements is independent of populated and industrialized areas, and these elements are usually not connected to air pollution. The spatial distribution of Factor 1 scores is 
presented in Figure 2. The highest contents of the elements were found in moss samples which were collected on Precambrian and Paleozoic shists or close to them. The presence of $\mathrm{Sr}$ in this group can be explained by the influence of the volcanic rocks in some areas of the country, especially in the area of Kratovo. The high content of these elements in the region of Bitola (Pelagonia valley) can be explained by fly ash emission from the lignite-burning power plant. Usually, the content of this element in mosses collected in northern European countries is much lower [50], but reported values for the same element in other Balkan countries [52-54], which are close to the values for Macedonia, indicate that a dry climate has a significant impact on the distribution.

Second strongest factor was Factor 2, explaining $18.3 \%$ of the total variability. The presence of $\mathrm{Cu}, \mathrm{Zn}, \mathrm{Cd}$ and $\mathrm{Pb}$ in this group (Figure 3) indicates that this is an anthropogenic geochemical association of elements. This factor is connected to industrial activity in Macedonia. A high content of these elements in mosses was observed near the towns of Skopje, Veles and Radovis, as well as in the eastern part of the country. By May 2003, a lead and zinc smelter plant was operational in the city of Veles. The open slag waste dump of this smelter in Veles still is contributing to pollution with $\mathrm{Cd}, \mathrm{Zn}$ and $\mathrm{Pb}$ in this region (Figures 4-6). The wind of Vardarec also contributes to pollution with these elements along the river of Vardar. The high density of road traffic in the region of Skopje, the presence of a central heating station in the town and an oil refinery in the vicinity of the town also contribute to the presence of these elements in the Skopje region. A zone with high values of $\mathrm{Cd}, \mathrm{Pb}$ and $\mathrm{Zn}$ (Figure 3) was found in the eastern parts of Macedonia as well, because of the operation of three lead and zinc mines (Sasa, Toranica and Zletovo) $[55,56]$ as well as one open pit copper mine on the southeast, near the city of Radoviš [34, 35] (Figure 7).

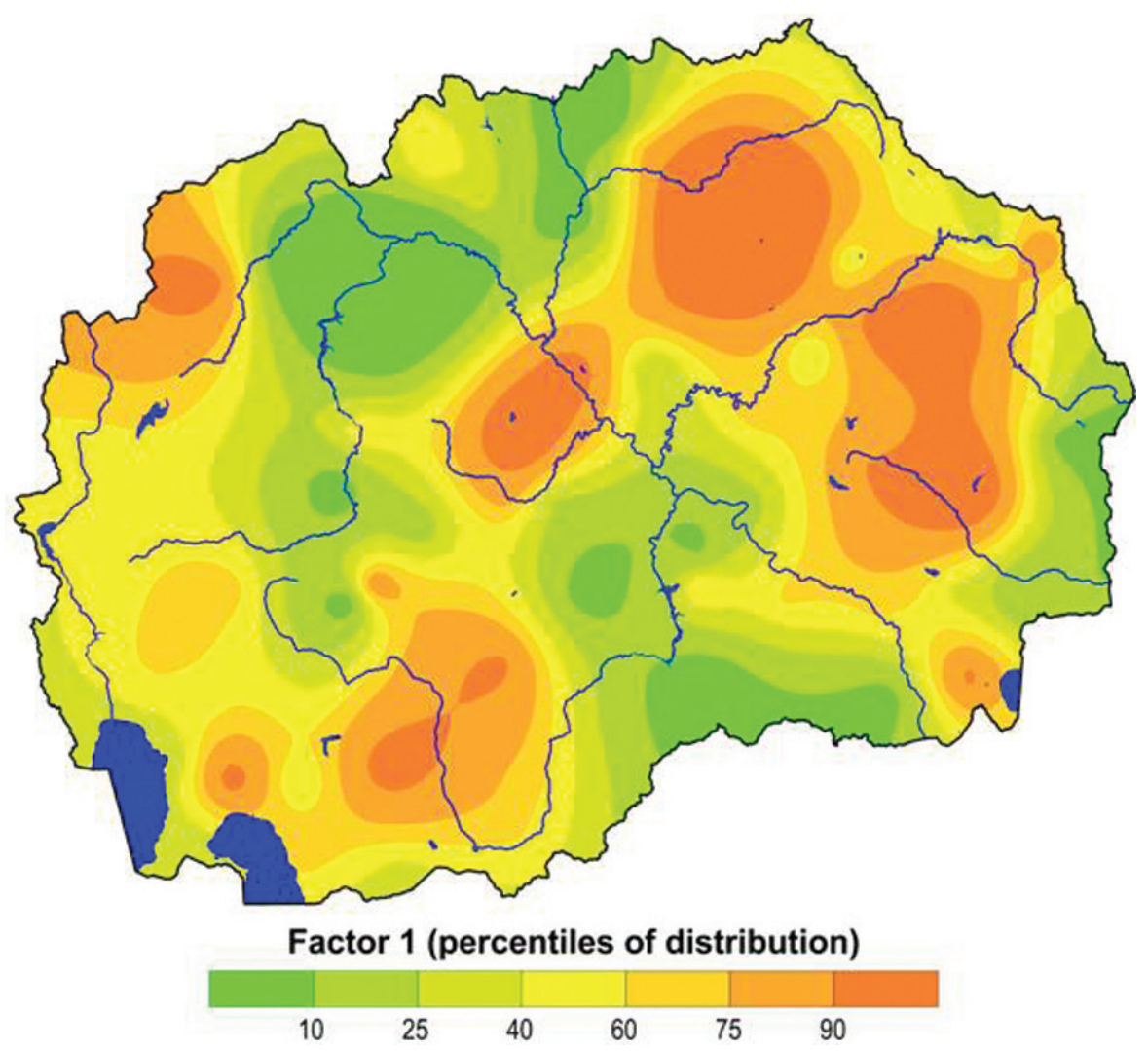

Fig. 2. Spatial distribution of Factor 1 scores (Al-Ba-Fe-Li-Sr-V) 


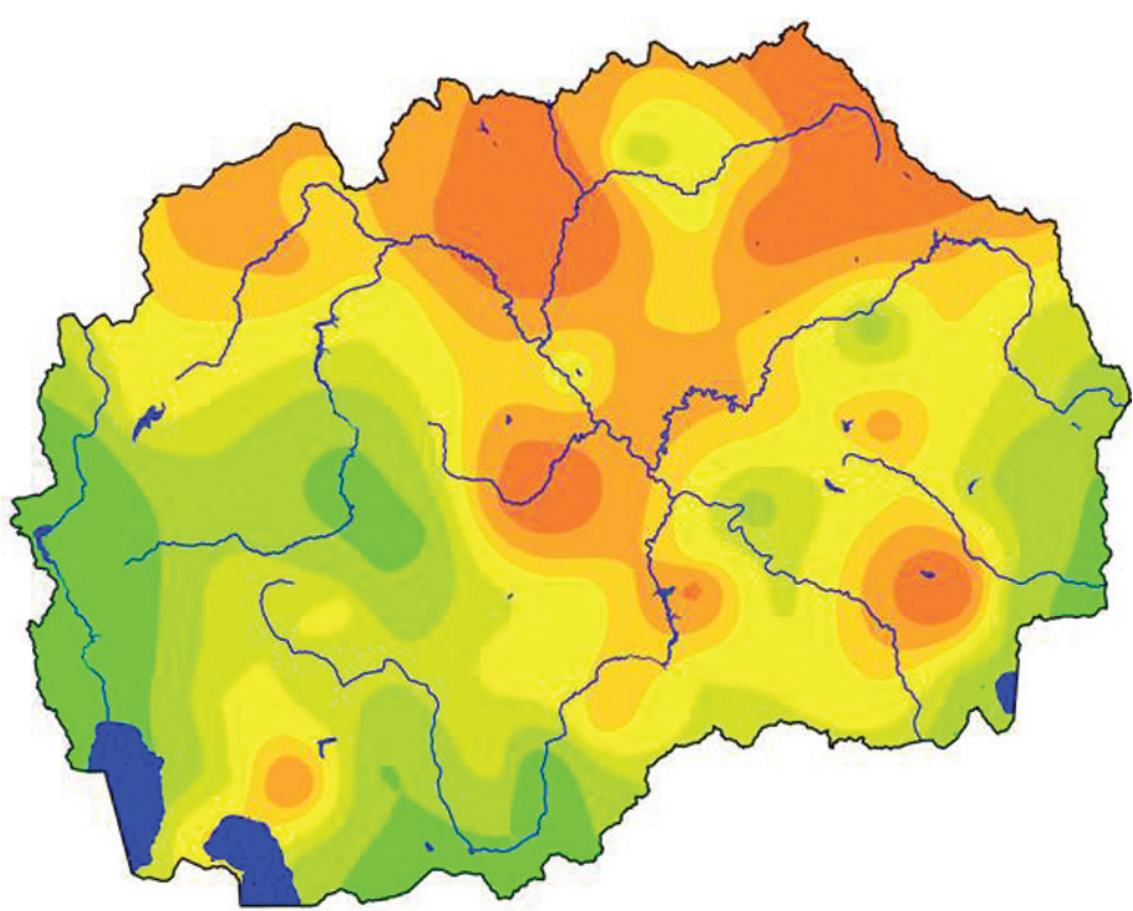

\section{Factor 2 (percentiles of distribution)}

$\begin{array}{llllll}10 & 25 & 40 & 60 & 75 & 90\end{array}$

Fig. 3. Spatial distribution of Factor 2 scores $(\mathrm{Cd}-\mathrm{Cu}-\mathrm{Pb}-\mathrm{Zn})$

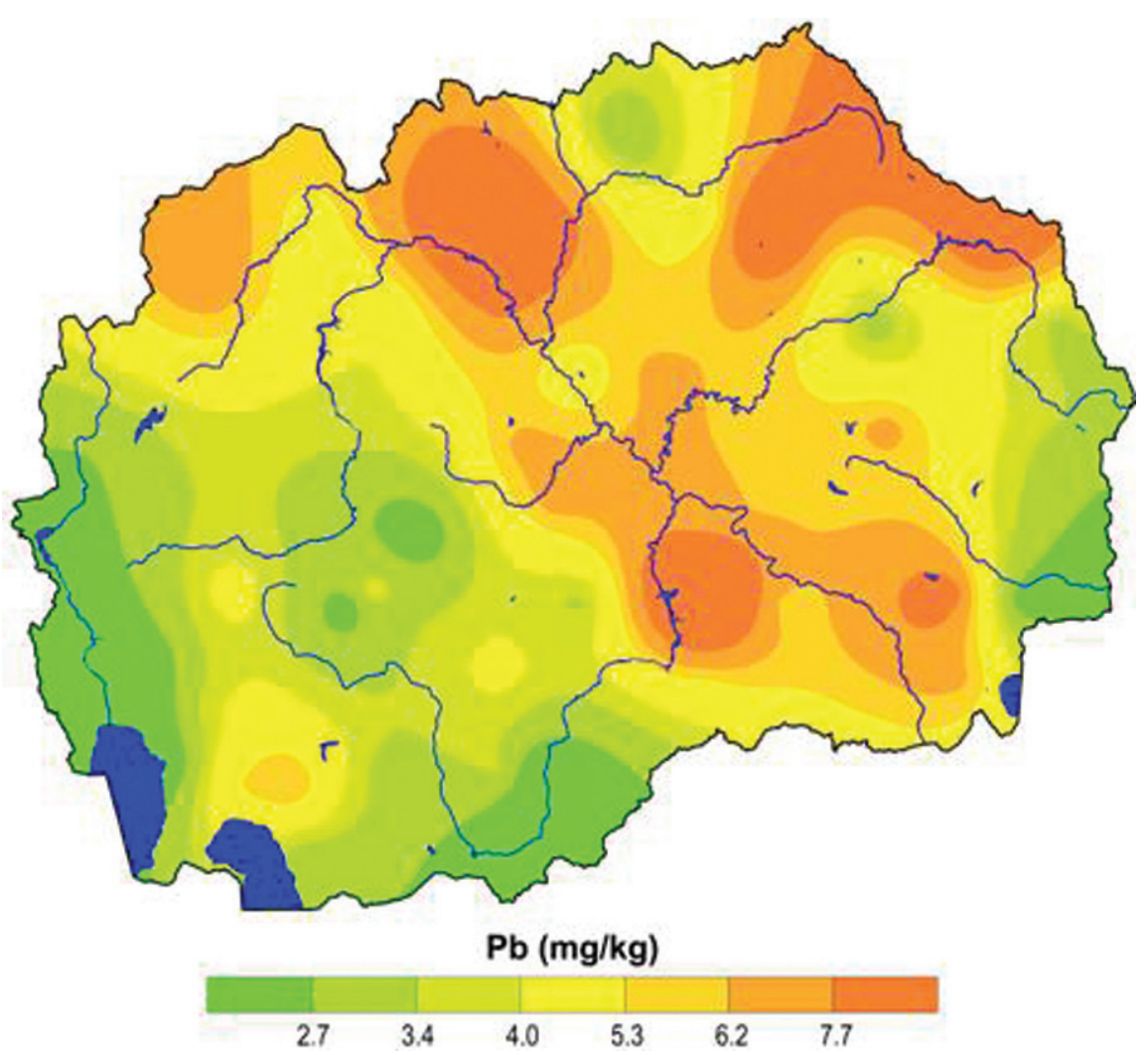

Fig. 4. Spatial distribution of lead 


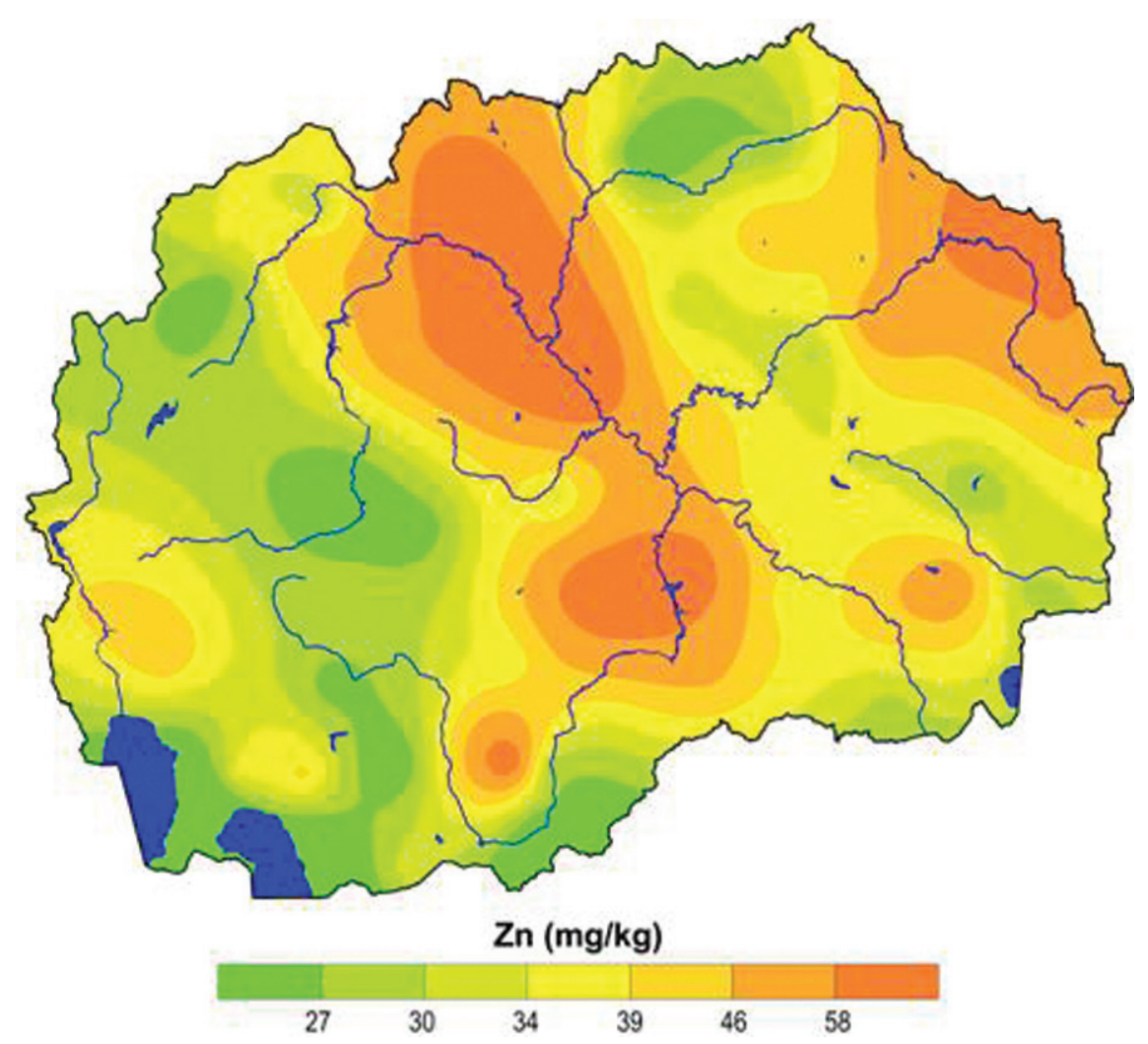

Fig. 5. Spatial distribution of zinc

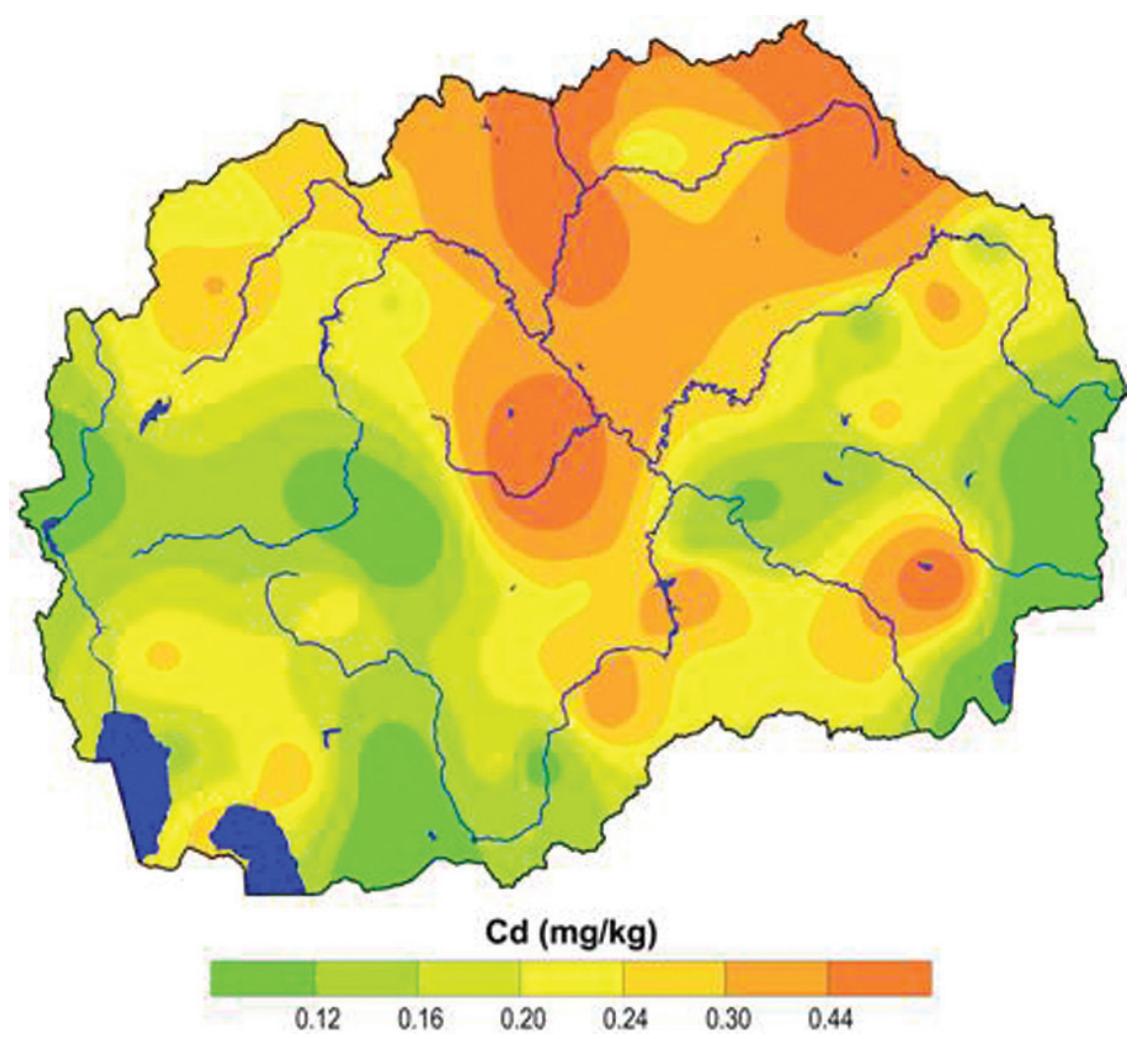

Fig. 6. Spatial distribution of cadmium 


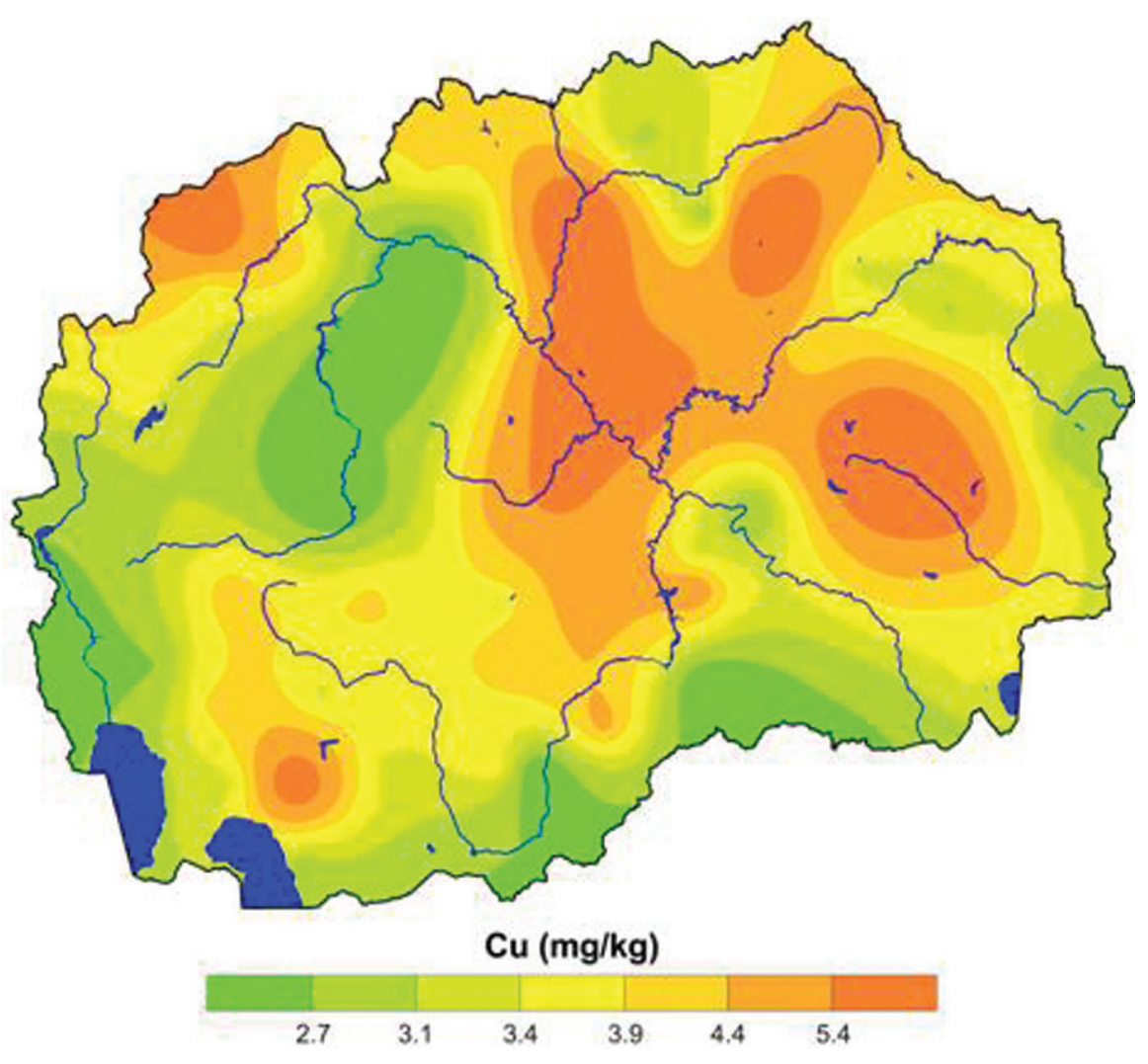

Fig. 7. Spatial distribution of copper

Factor $3(\mathrm{Mg}, \mathrm{Cr}$ and $\mathrm{Ni}$ ) represents a mixed (geogenic-anthropogenic) association of elements. The specific content of these elements is primarily affected by natural factors such as lithological background, but there is an anthropogenic influence as well. High values of aforementioned elements were clearly isolated in the Vardar zone (Figure 8), where Paleogene (Pg) flysch sediments and $\mathrm{Ng}$ sediments occur that have been repeatedly demonstrated in Macedonia [33-37]. The geogenic influence of nickel, reaching the locality of Groot near the town of Veles (central part), is also present $[55,56]$. High contents of these elements were found in mosses along the Vardar and Crna river valleys (Figure 8), where the constant flow of air masses is present in both directions [57]. High concentrations of Ni were present near the ferro-nickel smelter in the town of Kavadarci (Figs. 9 and 10) situated in the south-central part of the country [36, 37, 58, 59], and near the former ferro-chromium smelter near Tetovo (northern part). The marine influence from the Aegean sea was most dominant along the
Vardar river, which explains the high content of $\mathrm{Mg}$ in the mosses in this region.

Factor 4 (P and $\mathrm{K}$ ) represents the second anthropogenic geochemical association of elements (Figure 11). It was the weakest factor, explaining $12.7 \%$ of total variability. For the first time, the content of $\mathrm{P}$ in moss samples collected from Macedonia was determined since the ICPAES analytical technique was used. NAA is not suitable for $\mathrm{P}$ due to interference from a ${ }^{30} \mathrm{Si}(\mathrm{n}$, $\gamma){ }^{31} \mathrm{Si}\left(\beta^{-}\right){ }^{31} \mathrm{P}$ reaction and the $(\mathrm{n}, \alpha)$ decay of phosphorus to aluminum via a ${ }^{31} \mathrm{P}(\mathrm{n}, \alpha){ }^{28} \mathrm{Al}$ reaction [60]. High values of these elements were found in the regions where agricultural activities are present in the country, i.e. near the towns of Bitola and Prilep (Pelagonia region), in the southwest of the country, Strumica in the southeast of the country, and the region of Polog, near the towns of Tetovo and Gostivar in the northwest of the country. An apparent reason for the high content of $\mathrm{K}$ and $\mathrm{P}$ in the moss samples collected in these regions is the usage of potassium and phosphorus fertilizers in agricultural activities. This conclusion 


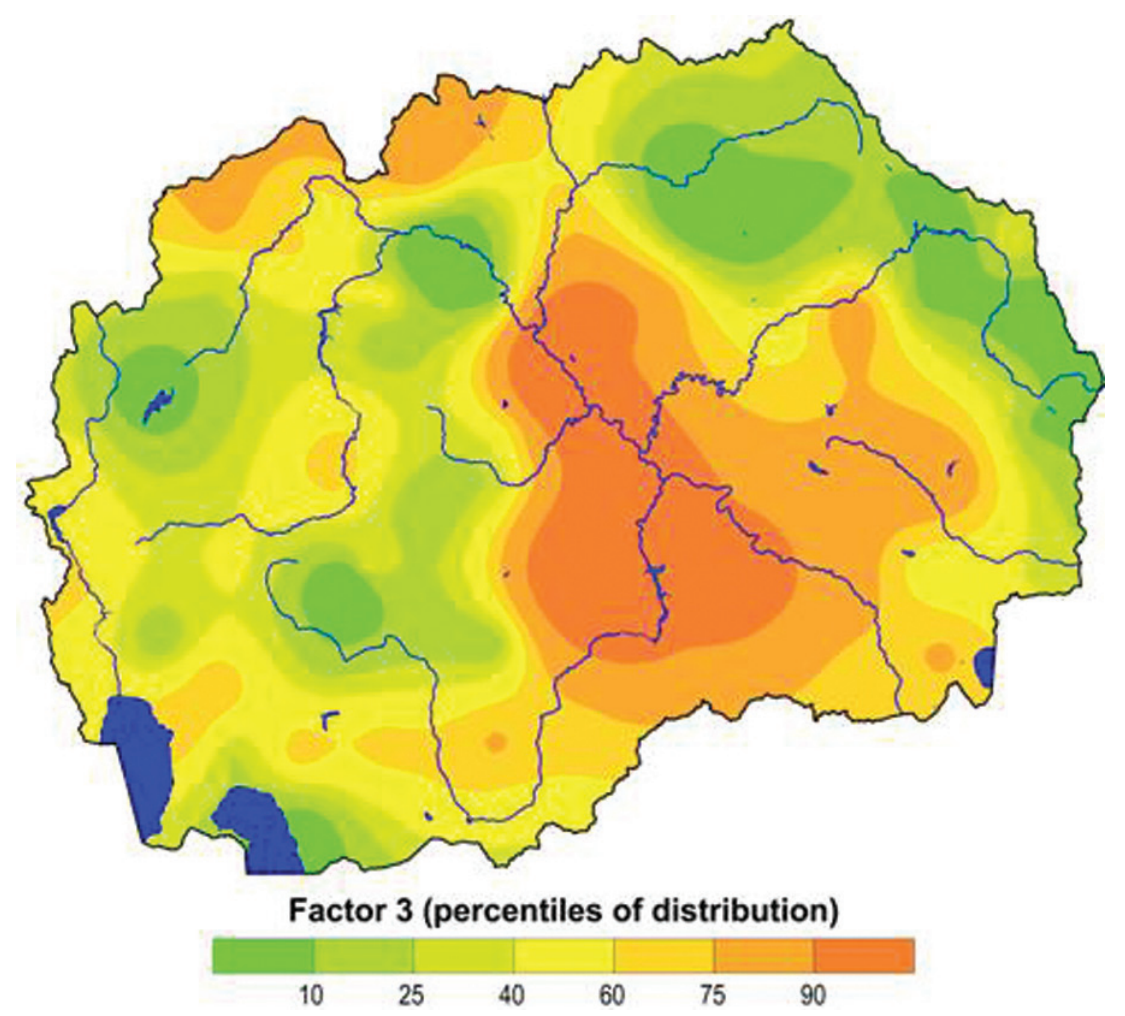

Fig. 8. Spatial distribution of Factor 3 scores (Cr-Mg-Ni)

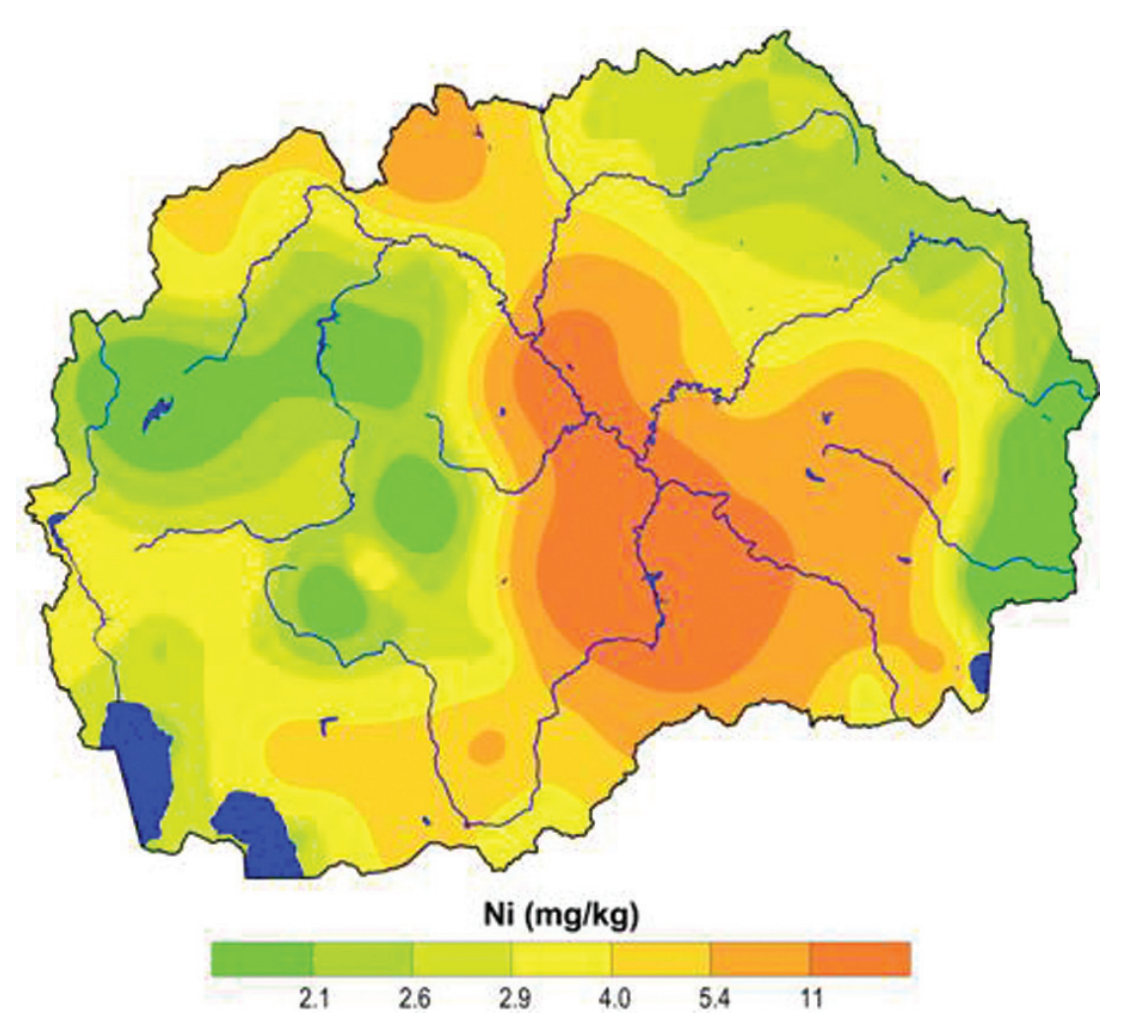

Fig. 9. Spatial distribution of nickel 


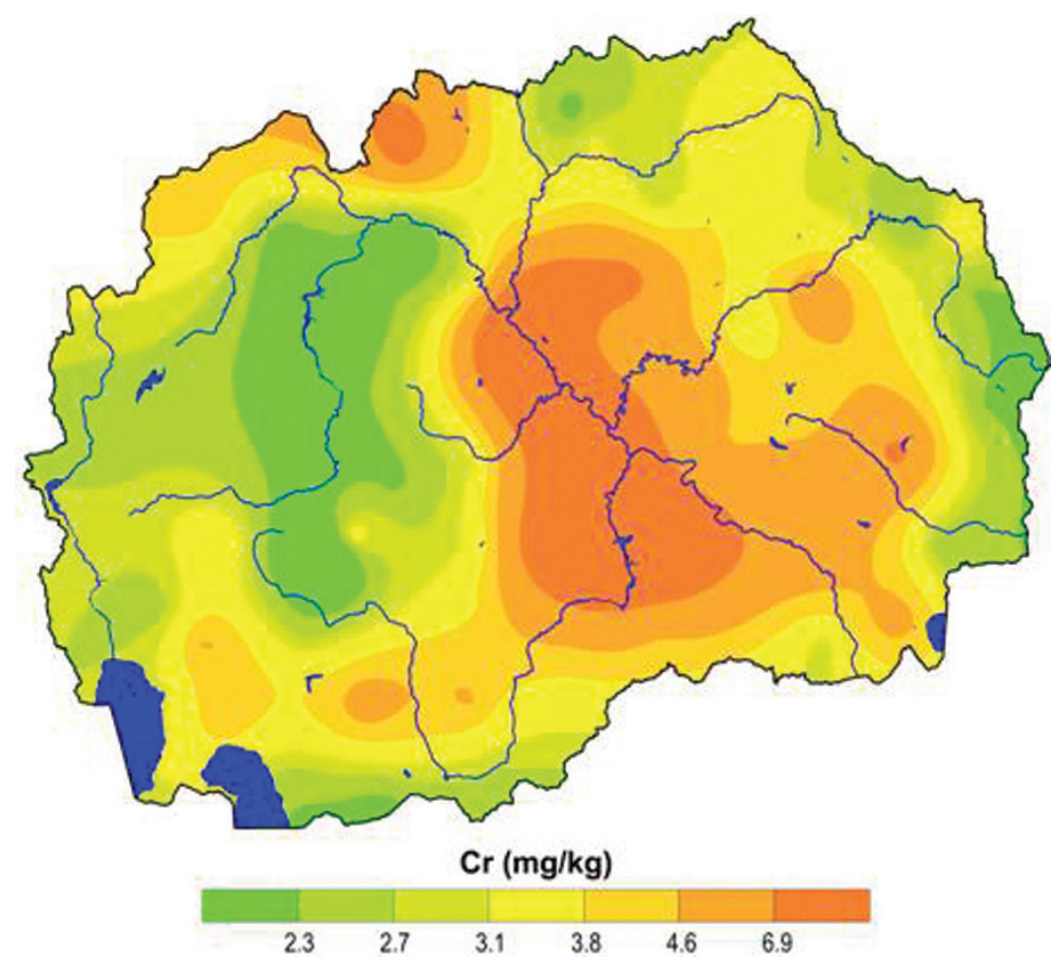

Fig. 10. Spatial distribution of chromium

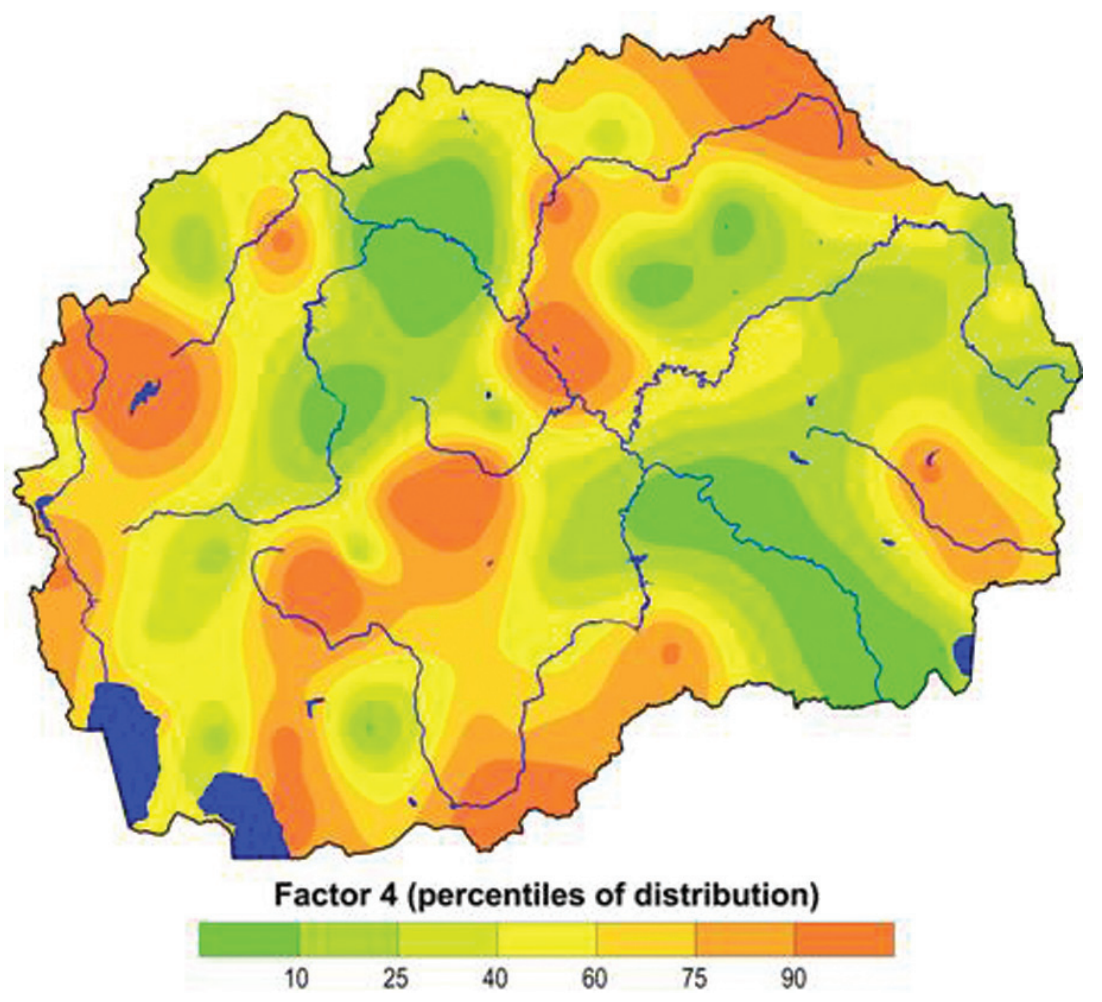

Fig. 11. Spatial distribution of Factor 4 scores (K-P) 
indicates the releasing of soil particles into the atmosphere, not just by wind erosion of local soils, but also by agricultural activities in some regions.

\section{CONCLUSION}

While most European countries have reported decreasing trends in the elemental content in mosses that are connected with anthropogenic sources, such as $\mathrm{Cd}, \mathrm{Pb}, \mathrm{Cr}, \mathrm{Ni}$ and $\mathrm{Zn}$, in the period from 2000 to 2005 , the data obtained for Macedonia show the opposite trend for the mentioned elements, except for $\mathrm{Cr}$. The results from 2010 showed a lower elemental content in the mosses for the mentioned elements than the results obtained in 2005 . Again, the most important pollution sources appear to be smelters of Skopje and Kavadarci, open slag dumps in Veles and Tetovo, the $\mathrm{Pb}$ $\mathrm{Zn}$ mines of Sasa, Toranica and Zletovo and the $\mathrm{Cu}$ mine of Bučim. Agricultural activities and the use of artificial fertilizers in some areas of the country have an influence on the content of $\mathrm{K}$ and $\mathrm{P}$ in mosses, indicating that emission of soil particles in these regions is higher due to this activity. In comparison with the results obtained in the 2010 moss survey in Norway, Macedonia has a higher median value for the elemental contents of practically all elements that are usually connected with air pollution. Higher maximum but lower median values for some of these elements in Norway indicate that the local pollution sources in Norway have a small or no effect on the air pollution of the entire country, which is not the situation in the Republic of Macedonia.

Acknowledgments. The authors are sincerely grateful to Professor Dr. Marina Cekova from the Institute of Biology, Faculty of Natural Sciences and Mathematics, Skopje, for determining the moss species.

\section{REFERENCES}

[1] H. T. Wolterbeek, Biomonitoring of trace element air pollution: Principles, possibilities and perspectives, Environ. Poll., 120, 11-21 (2002).
[2] K. Szczepaniak, M. Biziuk, Aspects if the biomonitoring studies using mosses and lichens as indicators of metal pollution, Environ. Res., 93, 221-230 (2003).

[3] Å. Rühling, G. Tyler, Heavy metal deposition in Scandinavia, Water, Air Soil Poll., 2, 445-455 (1973).

[4] Å. Rühling, E. Steinnes, Atmospheric heavy metal deposition in Europe 1995-1996, NORD Environment, NORD 1998:15, 1998.

[5] H. Harmens, A. Buse, P. Büker, D. Norris, G. Mills, B. Williams, Heavy metal concentrations in European mosses: 2000/2001 survey, J. Atmos. Chem., 49, 425-436 (2004).

[6] S. S. Groet, Regional and local variations in heavy metal concentrations of bryophytes in the northeastern United States, Oikos, 27, 445-456 (1976).

[7] K. E. Percy, Heavy metal and sulphur concentrations in Sphagnum magellanicum Brid. in the maritime provinces, Canada, Water Air Soil Poll., 19, 341-349 (1982).

[8] C. Elias, E. A. N. Fernandes, E. J. França, M. A. Bacchi, F. S. Tagliaferro, Native bromeliads as biomonitors of airborne chemical elements in a Brazilian restinga forest. J. Radioanal. Nucl. Chem., 278, 423-427 (2008).

[9] C. S. L. Lee, X. Li, G. Zhangb, X. Pengb, L. Zhangc, Biomonitoring of trace metals in the atmosphere using moss (Hypnum plumaeforme) in the Nanling Mountains and the Pearl River Delta, Southern China. Atmos. Environ., 39, 397-407 (2005).

[10] D. Čeburnis, D. Vailiulis, Investigation of absolute metal uptake efficiency from precipitation in moss. Sci. Total Environ., 226, 247-253 (1999).

[11] O. A. Culicov, R. Mocanu, M. V. Frontasyeva, L. Yurukova, E. Steinnes, Active moss biomonitoring applied to an industrial site in Romania: relative accumulation of 36 elements in moss-bags, Environ. Monit. Assess., 108, 229-240 (2005).

[12] M. Aničić, M. Tasić, M. V. Frontasyeva, M. Tomašević, S. Rajšić, Z. Mijić, A. Popović, Active moss biomonitoring of trace elements with Sphagnum girgensohnii moss bags in relation to atmospheric bulk deposition in Belgrade, Serbia, Environ. Poll., 157, 673-679 (2009).

[13] M. Aničić, M. Tomašević, M. Tasić, S. Rajšić, A. Popović, M. V. Frontasyeva, S. Lierhagen, E. Steinnes, Monitoring of trace element atmospheric deposition using dry and wet moss bags: Accumulation capacity versus exposure time, J. Hazard. Mater., 171, 182-188 (2009). 
[14] E. Gjengedal, E. Steinnes, Uptake of metal ions in moss from artificial precipitation. Environ. Monit. Assess., 14, 77-87 (1990).

[15] T. Berg, O. Røyset, E. Steinnes, Moss (Hylocomium splendens) used as biomonitor of atmospheric trace element deposition: Estimation of uptake efficiencies. Atmos. Environ., 29, 353-360 (1995).

[16] T. Berg, E. Steinnes, Use of mosses (Hylocomium splendens and Pleurozium schreberi) as biomonitors of heavy metal deposition: From relative to absolute values. Environ. Poll., 98, 61-71 (1997).

[17] D. Čeburnis, E. Steinnes, K. Kveitkus, Estimation of metal uptake efficiencies from precipitation in mosses in Lithuania. Chemosphere 38, 445-455 (1999).

[18] International Cooperative Programme on Effects of Air Pollution on Natural Vegetation and Crops Heavy Metals in European Mosses: 2005/2006 survey, Monitoring manual, http://icpvegetation. ceh.ac.uk/ publications.htm, 2005.

[19] L. Galsomiès, M. A. Letrouit, C. Dechamps, D. Savanne, M. Avnaim, Atmospheric deposition in France: Initial results on moss calibration from the 1996 biomonitoring, Sci. Total Environ., 232, 39-47 (1999).

[20] L. Barandovski, M. Cekova, M. V. Frontasyeva, S. S. Pavlov, T. Stafilov, E. Steinnes, V. Urumov, Air pollution studies in Macedonia using the moss biomonitoring technique, NAA, AAS and GIS technology; Preprint E18-2006-160, Joint Institute for Nuclear Research, Dubna, 2006.

[21] L. Barandovski, M. Cekova, M. V. Frontasyeva, S. S. Pavlov, T. Stafilov, E. Steinnes, V. Urumov, Atmospheric deposition of trace element pollutants in Macedonia studied by the moss biomonitoring technique, Environ. Monitor. Assess., 138, 107-118 (2008).

[22] L. Barandovski, M. V. Frontasyeva, T. Stafilov, R. Šajn, S. Pavlov, V. Enimiteva, Trends of atmospheric deposition of trace elements in Macedonia studied by the moss biomonitoring technique, $J$. Environ. Sci. Heal. A, 47, 2000-2015 (2012).

[23] J. Stamenov, M. Iovchev, B. Vachev, E. Gueleva, L. Yurukova, A. Ganeva, M. Mitrikov, A. Antonov, A. Srentz, Z. Varbanov, I. Batov, K. Damov, E. Marinova, M. V. Frontasyeva, S. S. Pavlov, L. P. Strelkova, New results from air pollution studies in Bulgaria (Moss survey 2000-2001), Preprint E14 2002-204, Joint Institute for Nuclear Research, Dubna 2002.
[24] S. Marinova, L. Yurukova, M. V. Frontasyeva, E. Steinnes, L. P. Strelkova, A. Marinov, A. G. Karadzhinova, Air pollution studies in Bulgaria using the moss biomonitoring technique, Ecol. Chem. Eng. S, 17, 37-52 (2010).

[25] M. V. Frontasyeva, T. Ye. Galinskaya, M. Krmar, M. Matavuly, S. S. Pavlov, E. A. Povtoreyko, D. Radnovic, E. Steinnes, Atmospheric deposition of heavy metals in northern Serbia and BosniaHerzegovina studied by the moss biomonitoring, neutron activation analysis and GIS technology, $J$. Radioanal. Nucl. Chem., 259, 141-144 (2004).

[26] O. Stan, A. Lucaciu, M. V. Frontasyeva, E. Steinnes, New results from air pollution studies in Romania. Proceedings of NATO ARW "Man-Made Radionuclides and Heavy Metals in Environment", M. V. Frontasyeva, P. Vater, V. P. Perelygin (Eds.), Kluwer Academic Publishers, NATO Science Series, IV Earth and Environmental Sciences, Vol. 5, 2001, pp. 179-190.

[27] S. Cucu-Man, R. Mocanu, O. Culicov, E. Steinnes, M. Frontasyeva, Atmospheric deposition of metals in Romania studied by biomonitoring using the epiphytic moss Hypnum cupressiforme, Int. J. Environ. Anal. Chem., 84, 845-854 (2004).

[28] E. Steinnes, T. Berg,. T. E. Sjøbakk, H. Uggerud, M. Vadset, Atmospheric deposition of heavy metals in Norway Nation-wide Survey 2000. Report, State Pollution Control Authority, Oslo 2001.

[29] H. Harmens, D. A. Norris, E. Steinnes, E. Kubin, J. Piispanen, R. Alber, Y. Aleksiayenak, O. Blum, M. Coşkun, M. Dam, L. De Temmerman, J. A. Fernández, M. Frolova, M. Frontasyeva, L. González-Miqueo, K. Grodzińska, Z. Jeran, S. Korzekwa, M. Krmar, K. Kvietkus, S. Leblond, S. Liiv, S. H. Magnússon, B. Maňkovská, R. Pesch, A. Rühling, J. M. Santamaria, W. Schröder, Z. Spiric, I. Suchara, L. Thöni, V. Urumov, L. Yurukova, H. G. Zechmeister, Mosses as biomonitors of atmospheric heavy metal deposition: spatial and temporal trends in Europe, Environ. Poll., 158, 3144-3156 (2010).

[30] H. Harmens, D. Norris, J. Aboal Viñas, R. Alber, Y. Aleksiayenak, M. Ashmore, L. Barandovski, T. Berg, R. Bermejo, O. Blum, A. Carballeira Ocaña, A. Çayir, M. Cokun, Mü. Cokun, M. Dam, H. Dieffenbach-Fries, D. Elustondo, E. Ermakova, A. Fernández Escribano, M. Florek, M. Frolova, M. Frontasyeva, L. Galsomiès, B. Godzik, L. González-Miqueo, K. Grodziska, K. Jarvis, Z. Jeran, C. Jordan, P. Kapusta, J. Karhu, M. Krmar, E. Kubin, K. Kvietkus, E. Lasheras, S. Leblond, S. 
Liiv, A. Lloyd, B. Makovská, S. Marinova, S.H. Magnússon J. Meresova, O. Nikodemus, T. Olsson, J. Oszlanyi, Y. Pankratova, R. Pesch, J. Piispanen, J. Poikolainen, D. Radnovich, C. Rauschde Traubenberg, A. Riss, A.. Rühling, J. J. M. Santamaría, L.W. Schröder, Z. Spiric, T. Stafilov, E. Steinnes, L. Strelkova, I. Suchara, J. Sucharová, G. Szarek-Ukaszewska, K. Szymon, G. Tabors, L. Thöni, G. De Temmerman, H. Uggerud, V. Urumov, L. Yurukova, K. Vergel, H. Zechmeister, Spatial and temporal trends in heavy metal accumulation in mosses in Europe (1990-2005), H. Harmens and D. Noris, eds., Programme Coordination Centre FOR THE ICP Vegetation, Centre for Ecology \& Hydrology, Natural Environment Research Council, Bangor, UK, 2008.

[31] State Statistical Office of the Republic of Macedonia, Population and Social Statistics, Skopje, Republic of Macedonia, 2011.

[32] T. Stafilov, R. Šajn, Z. Pančevski, B. Boev, M. V. Frontasyeva, L. P. Strelkova, Heavy metal contamination of surface soils around a lead and zinc smelter in the Republic of Macedonia, J. Hazard. Mater., 175, 896-914 (2010).

[33] T. Stafilov, R. Šajn, B. Boev, J. Cvetković, D. Mukaetov, M. Andreevski, S. Lepitkova, Distribution of some elements in surface soil over the Kavadarci Region, Republic of Macedonia. Environ. Earth. Sci., 61, 1515-1530 (2010).

[34] B. Balabanova, T. Stafilov, R. Šajn, K. Bačeva, Characterisation of heavy metals in lichen species Hypogymnia Physodes and Evernia Prunastri due to biomonitoring of air pollution in the vicinity of copper mine, Int. J. Environ. Res., 6, 779-792 (2012).

[35] B. Balabanova, T. Stafilov, R. Šajn, K. Bačeva, Distribution of chemical elements in attic dust as reflection of lithology and anthropogenic influence in the vicinity of copper mine and flotation. Arch. Environ. Contam. Toxicol., 6, 173-184 (2011).

[36] K. Bačeva, T. Stafilov, R. Šajn, C. Tănăselia, S. I. Popov, Distribution of chemical elements in attic dust in the vicinity of ferronickel smelter plant, Fresen. Environ. Bull., 20, 2306-2314 (2011).

[37] K. Bačeva, T. Stafilov, R. Šajn, C. Tănăselia, Moss biomonitoring of air pollution with heavy metals in the vicinity of a ferronickel smelter plant, J. Environ. Sci. Health A, 47, 1-13 (2012).

[38] N. Dumurdzanov, T. Serafimovski, B. C. Burchfiel, Cenozoic tectonics of Macedonia and its relation to the South Balkan extensional, Geosphere 1, $1-22$ (2005).
[39] G. Jovanovski, B. Boev, P. Makreski, Minerals from the Republic of Macedonia with an introduction to mineralogy. Macedonian Academy of Sciences and Arts, Skopje, 2012.

[40] United Nations Economic Commission for Europe Convention on Long-Range, Transboundary Air Pollution monitoring of Atmospheric Heavy Metal Deposition in Europe Using Bryophytes, Monitoring Manual 2005/2006 Survey, 2005.

[41] B. Balabanova, T. Stafilov, K. Bačeva, R. Šajn, Biomonitoring of atmospheric pollution with heavy metals in the copper mine vicinity located near Radoviš, Republic of Macedonia, J. Environ. Sci. Health, Part A, 45, 1504-1518 (2010).

[42] E. Steinnes, Å. Rühling, H. Lippo, A. Mäkinen, Reference material for large-scale metal deposition surveys. Accredit. Qual. Assur., 2, 243-249 (1997).

[43] G. W. Snedecor, W. G. Cochran, Statistical methods, The Iowa State University Press, Ames, Iowa, 1967.

[44] M. Hollander, D. A. Wolfe, Nonparametric statistical methods, $2^{\text {nd }}$ Edition, John Wiley \& Sons, New York, 1999.

[45] R. W. Le Maitre, Numerical Petrology, Statistical Interpretation of Geochemical Data. Elsevier, Amsterdam, 1982.

[46] J. C. Davis, Statistic and Data Analysis in Geology, Wiley \& Sons, New York, 1986.

[47] C. Reimann, P. Filzmoser, R. G. Garrett, Factor analysis applied to regional geochemical data: problems and possibilities. App. Geochem., 17, 185-206 (2002).

[48] P. Filzmoser, R. G. Garrettb, C. Reimann, Multivariate outlier detection in exploration geochemistry. Comput. Geosci., 31, 579-587 (2005).

[49] R. Beelen, G. Hoek, E. Pebesma, D. Vienneaud, K. de Hoogh, D. J. Briggs, Mapping of background air pollution at a fine spatial scale across the European Union. Sci. Total. Environ., 407, 1852-1867 (2009).

[50] E. Steinnes, T. Berg, H. T. Uggerud, K. A. Pfaffhuber, Atmostcerisk nedfall av tungmetaller $i$ Norge Landsomfattende undersøkelse i 2010, Stallig program for forurensningsovervåking, Rappotur 1109/2011, 2011 (in Norwegian).

[51] F. W. Fifield, P. J. Haines, Environmental Analytical Chemistry, Blackie Academic \& Professional, London, 1995. 
[52] Z. Špirić, M. Frontasyeva, E. Steinnes, T. Stafilov, Multi-element atmospheric deposition study in Croatia, Int. J. Environ. Anal. Chem., 92, 12001214 (2012).

[53] S. Marinova, L. Yurukova, M. V. Frontasyeva, E. Steinnes, L. P. Strelkova, A. Marinov, A. G. Karadzhinova, Air pollution studies in Bulgaria using the moss biomonitoring technique, Ecol. Chem. Eng. S, 17, 37-52 (2010).

[54] M. Coşkun, M. V. Frontasyeva, E. Steinnes, A. Y. Çotuk, S. S. Pavlov, A. S. Sazonov, A. Çayir, M. Belivermis, Atmosperic deposition of heavy metals in Thrace studied by analysis of moss (Hypnum cupresiforme), Bull. Environ. Contam. Toxicol., 74, 201-209 (2005).

[55] T. Stafilov, L. Peeva, B. Nikov, A. de Koning, Industrial hazardous waste in the Republic of Macedonia, Applied Environmental Geochemistry - Anthropogenic Impact on the Human Environment in SE Europe, Proceedings Book (R. Šajn, G. Žilbert, J. Alijagić, Eds.), Geological Survey of Slovenia, Ljubljana, 2009, pp. 108-112.

[56] J. M. Serafimovska, S. Arpadjan, T. Stafilov, S. Ilik Popov, Dissolved inorganic antimony, selenium and tin species in water samples from various sampling sites of river Vardar (Macedonia/Greece), Maced. J. Chem. Chem. Eng., 30, 181-188 (2011).

[57] A. Lazarevski, Climate in Macedonia, Kultura, Skopje Republic of Macedonia, 1993 (in Macedonian).

[58] T. Stafilov, R. Šajn, B. Boev, J. Cvetković, D. Mukaetov, M. Andreevski, Geochemical atlas of $\mathrm{Ka}$ vadarci and the environs, Faculty of Natural Sciences and Mathematics, Skopje, 2008.

[59] T. Stafilov, R. Šajn, B. Balabanova, K. Bačeva, Distribution of heavy metals in attic and deposited dust in the vicinity of copper ore processing and ferronickel smelter plants in the Republic of Macedonia, In: Dust: Sources, Environmental Concerns and Control, L. B. Wouters, M. Pauwels (Eds.), Science Publishers, Hauppauge, NY; ISBN: 9781-61942-566-8, 2012.

[60] F. De Corte, E. Steinnes, P. de Neve, A. Simonits, Importance of double neutron-capture as a secondorder reaction interference in NAA, J. Radioanal. Nucl. Chem., 215, 279-282 (1997). 
